\title{
How Can We Develop Immunity against COVID-19 and Defeat It \\ Stephen $\mathrm{P}^{1^{*}}$
}

${ }^{1}$ National Innovation Foundation, Ahmadabad, Gujarat, India

Corresponding Author: Pramod Stephen

Address: Innovator, Christian Church PO Sugauli 845456, East Champaran, Bihar, India; Tel: +91-9199646455; Email: pramod_stephen@rediffmail.com

Received date: o9 April 2020; Accepted date: 11 April 2020; Published date: 16 April 2020

Citation: Stephen P. How Can We Develop Immunity against COVID-19 and Defeat It. Diab Res Open Access. 2020 Apr 16;2(1):9-11.

Copyright (C) 2020 Stephen P. This is an open-access article distributed under the Creative Commons Attribution License, which permits unrestricted use, distribution, and reproduction in any medium, provided the original work is properly cited.

\section{Keywords}

COVID-19; Bile Juice; WHO

We know that Corona Virus develops in animals, birds and humans' body. Now it is a pandemic and many people are dying with each passing day and the number of patients is increasing every hour.

If we do not control it then it is dangerous for humanity. As we know the incubation period for COVID 19 is 1 to 14 days and it's live in the environment for 12 to 14 hours. The only solution to the spread of the virus is by social distancing.

As we know that it affects the person with low immunity so it is advised for all people to have a balanced diet, exercise daily and spend time in meditation for increasing immunity. I want to share a natural method to develop and increase the immunity power by the bile juice of animals, birds and we can try for corona virus too.

\section{Structure of COVID-19}

It is a composite protein/glycan shield by cryo.

\section{How it's work}

As we know that it is shield by proteins and glycan and bile juice breaks the protein and fats and supports digestion in the small intestine and Ethyl alcohol/rectified spirit kills the virus. If we use this combination then people will get strength and bile juice works as stem cells and rapidly runs in the blood. It helps in reducing blood sugar levels and fats in the blood as it boosts functions of Pancreas, liver and improves metabolism.

\section{Material \& Method}

Take an animal, birds, and fish chopped bile juice and mixed it with 50\% Bile juice and 50\% ethyl alcohol/rectified spirit and shake well in a bottle and keep it for 12 hours. After 12 hours all particles will sit at the bottom and we can use 1 drop upper site extract by oral administration. Repeated dose along with other drugs, it can develop immunity because I use it and found fruitful result in cough cold and digestion. I hope that it will kill all kinds of Virus and people will recover from this deadly virus. It is my humble request to the WHO and every Government agency to experiment on this topic and save the world by COVID19.

\section{Note}

We can use 50\% ethyl alcohol and 50\% bile juice 
Citation: Stephen P. How Can We Develop Immunity against COVID-19 and Defeat It. Diab Res Open Access. 2020 Apr 16;2(1):9-11.

\section{Opinion Article}

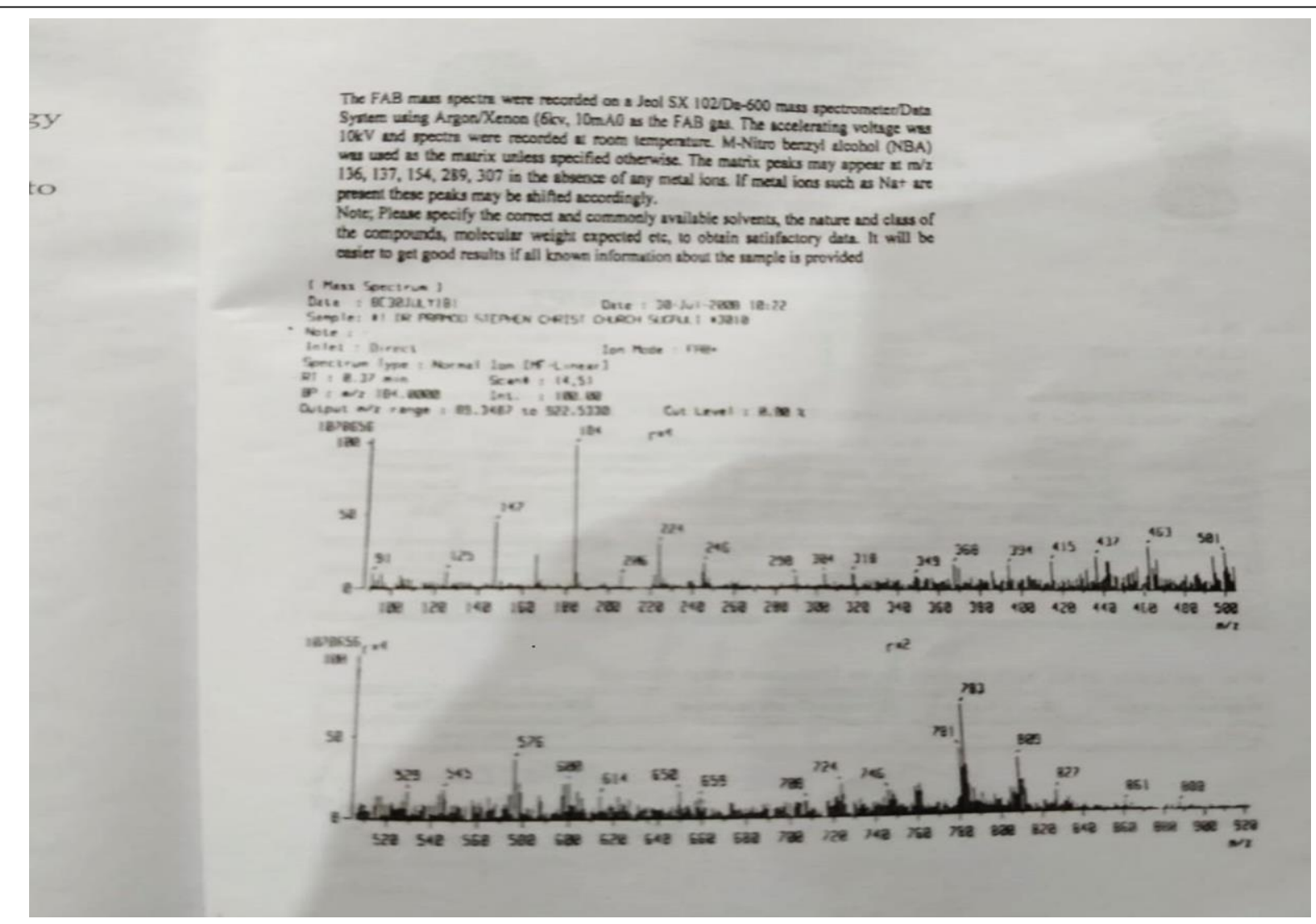

Fig-1:

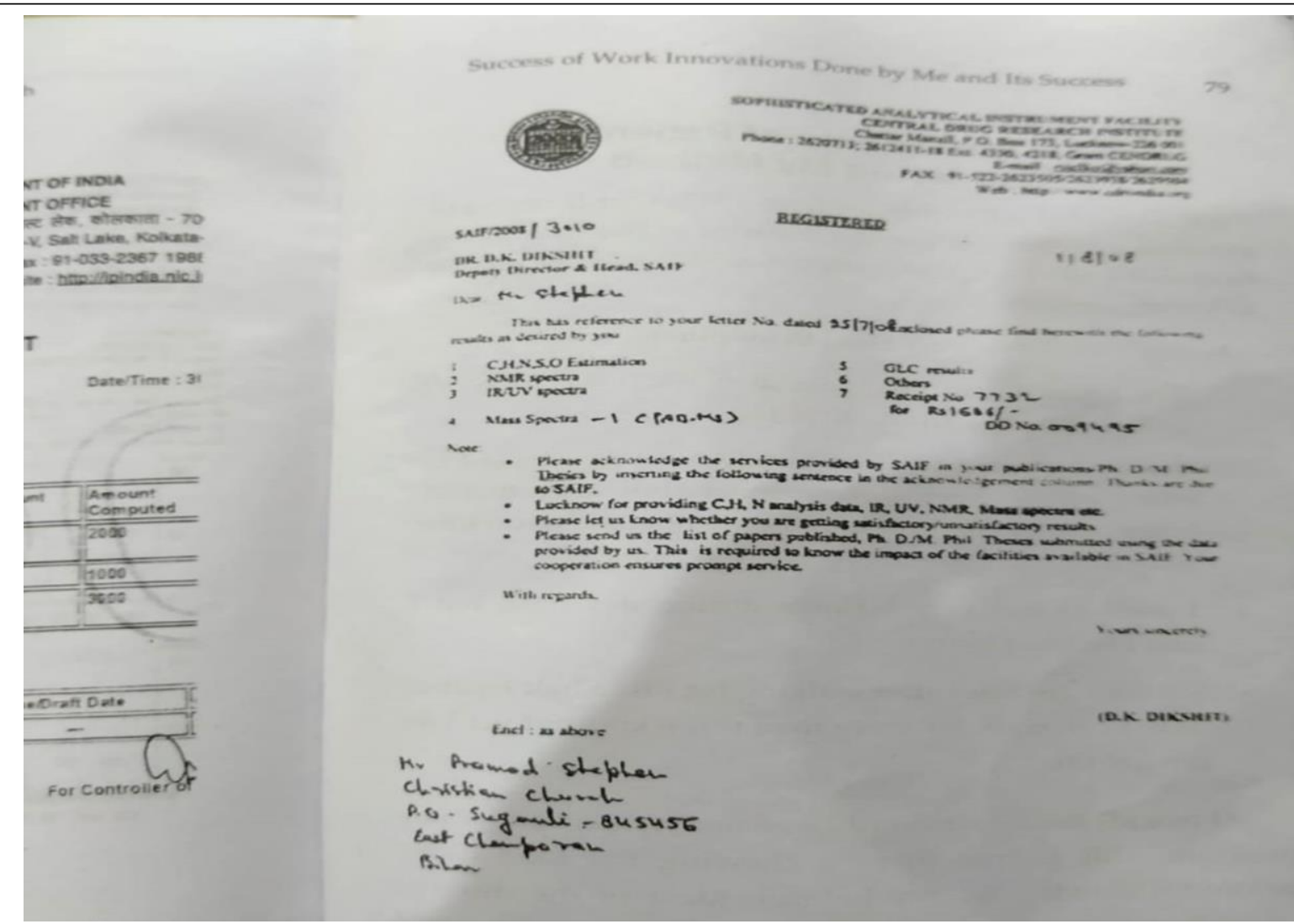



16;2(1):9-11.

and mix and give to critical patients for the experiment. I have attached the report from the Central Drug Research Institute Lucknow about the analysis of substance that no harmful substance is present in it (Fig-1 and Fig-2). Although the taste is bitter, it is lifesaving in critical circumstances and vaccines can be made using this composition. 